\title{
The Bullet
}

\section{Speer Morgan}

I was six years old the Saturday Grandfather Slate showed me around the store. He talked to me seriously that day for the first and only time, although he lived another fourteen years, in his right mind a good portion of that time-until the hour he walked out of Slate Wholesale Hardware, got into his forty-eight Plymouth, put it in second (he never used first) and drove from the parking lot straight across the street, over the curb and up the lawn of the old courthouse, cracking the axle of a Yankee cannon and running head on into a brick wall, knocking a handful of shingles loose from the ceiling and shattering a courtroom window that the Park Service claimed had been there since 1876, when Judge Isaac C. Parker sentenced his first hanging. In the letter I received at college, Mother said that the family was proud that Grandfather had gone to work on his last day.

My father was with me at Slate Hardware that afternoon in 1952-it was late Saturday-going over some orders and attending the weekly sales conference with Austin Slate, Jr. I wandered into the dusty high-ceilinged office which Grandfather Slate had occupied as president for thirty-five years and which doubled as an auxiliary sporting-goods stockroom. I wanted to see the Winchester bullet display, not Grandfather, who seemed to be from another planet, a dried-up old lizard-man with incongruous wet red eyes that floated behind his face, and utterly slow movements, as if his bones were summer weeds threatening to snap. He was so careful with each movement that he made me impatient, made me want to dance around him and say, "Grandfather, get a move on!" I knew that was impossible, so I usually tried to avoid him. That day he was asleep on the black leather couch that stood between gloomy shelves of fishing lures and spinning reels, lying with his hands clasped on his stomach. He looked like he would never move. On the wall above a roll-top desk was the display, with thirty-six bullets and shells on it, including an eight-gauge shotgun shell, cutaways showing powder and wadding and a cowboy killing a huge, slavering grizzly bear in the background. It was irresistable, especially the eight-gauge 
shell, which my brother had told me could knock down a brick wall ( I did not know then that not even my grandfather's Plymouth could knock down a brick wall), and I stood on the desk chair to see it more closely, to touch it, when his raspy whisper scared me nearly into mid-air, "Have to prop an eight-gauge or it will bust you."

I must have crouched to jump, because children were definitely not supposed to climb on furniture, but he did not order me off. Instead he sat on the edge of the couch, put his pipe in his mouth and told me about the time he dislocated his shoulder at a turkey shoot with an eight-gauge. He spoke the tale quietly into the gloom, not noticing me fixed standing on the chair until the last, when he took the pipe out of his mouth and looked at me with a smile that cracked his old lizard face and showed two yellow teeth. "And it hurt when John Harper set it, too. Served a young buck right. I had to eat that turkey in a sling."

And then we were on the elevator in the stockroom, a huge platform of splintery greasy planks, open on all sides so that you could see into the labyrinths of general hardware-stoves, rakes, fans, hinges, lawn mowers, guns, fishing boats, kegs of nails, bullets, toasters, toilets, hammers, shears, chicken wire, lightning rods-as we glided upward toward a dark hole swallowing the cable in the topmost ceiling. There was a black man up there who rolled the oily steel rope onto a wooden spindle. He waited for Grandfather's signal. I feared that we would not stop and the hole would swallow us. Then we would have to walk down a steep crooked staircase with no banister and crawl through holes and small doors to get out. Or if he did not pull the rope that he held with his funny old cricket hand we would squash against the ceiling and then fall six floors. I would have to jump just as we hit bottom to keep from getting killed. I wanted to help him pull the rope in time, but if I moved my weight, the platform might lose its balance, for there were no walls around it. I held as still as I could, my heart pumping, ready to save my life. The elevator stopped a good two feet above the top floor; he pulled the other rope and we descended below the rafters. My stomach came up my throat when he cursed, and I was just about to vault to safety when he jiggled the ropes and inched us level with the floor.

Walking past shelves and shelves of dry-smelling rope, I avoided cracks between the planks wide enough to see through to the floor below us. Grandfather stopped beside a spindle of white cord that stood as tall as me and twice as round. He cursed it, then took out a match and lit the end of the cord and held it while it sizzled. I backed away, again uneasy, and asked him if that was dynamite.

"Hell no, it's a piece of nylon rope. Think I'd blow up my own store? You should always close off nylon after you cut it or it will frazzle out. Damn kids don't respect the stock-no use telling me they do. Come over here and I'll tell you about dynamite." At the window we were so high-five stories high-that we could see the Arkansas River curve and curve like a snake. I already knew that Oklahoma was on the other side. "That river coming into the Arkansas is the Poteau. You ever hear of that?"

"No." 
"Well it is. We got our drinking water out of it during the war ... I don't know which one ... I guess the first one. Brown as a cow pond. They called it Poteau Punch. Drink too much of it and you'd get constipated. Look over there -pay attention-about a half-mile up the Poteau was where we kept our dynamite. You see over there?"

"I don't see anything."

"Ain't anything to see. It blew up in 1897. I was twenty years old the day it blew up and we ain't had a powderhouse since."

I looked and looked out the window, not knowing what to say.

"There were three people over there fishing and we couldn't find any part of them. Blew them to smithereens as far as we could tell. I was riding the ferry back across the river after a week of selling pots and pans to the Indians. Damn Indians were the best customers we ever had. They would buy pots and pans and then a week later they'd buy some more. One winter I found out they were using them for sleds, sitting in them and holding the handle and sliding down the hills. I caught a grown Cherokee, the son of a customer of mine, ran a little store in Oneeta, name of Frank Sad Horse. I won't forget the old coot, must have been two hundred years old. Twice as old as I am ..."

Grandfather was no longer talking to me. He was looking out the window toward Oklahoma. I asked him what he had caught Frank Sad Horse's son at.

"Sliding down a hill-I already told you-in a sixteen-inch frying pan. I peed in my pants I laughed so hard. Young Frank didn't like it either. I don't know why; I guess I got his pride up. I was a buck then myself. Old Frank used to have a slave, a nigger the name of Wick that stayed with him after the War Between the States. He and old Frank played checkers, far as I could tell, day and night. The slowest checkers players I ever saw; they could sit there and think about the next move long enough for me to take stock, write up a two-page order and maybe sell him the newest stove out of Cleveland. I never did see them move once. Wick was on the ball though. I'd trade him for any three white men we got down there right now. He talked Cherokee, Creek, Choctaw and I wouldn't doubt Apache. I would have carried him along with me to sell hardware if he'd left Frank." He stared out the window, his pipe in his mouth, under the bowl a drop of saliva forming that sparkled yellow in dust-filtered sunlight. I looked at the cannon on the old courthouse lawn, wondering if we could get one like it to put in our front yard. That would be a good way to make a lot of friends; I knew it would. A cannon would be nice down by the highway. We lived a long way from town (three miles) and it took something special to lure friends out there. A cannon would be just right. I would polish it every day and roll it up to the shed when it rained.

He was looking down at me. "What was I talking about, Austin?"

I did not know how to say what he was talking about.

"Pay attention now boy. You were asking me about the fishermen that got blown up over on the Poteau. One of them was a no good Indian and two of them were no good white men, so it didn't matter too much. The kind that would be catfishing on a work day. My father put on a good funeral for them, anyway 
-fact of the matter, he put on a separate funeral for all three of them. Mock funeral I guess it was, since they couldn't find any part of them. He did it right, too. Had every damn empolyee of Slate Hardware down to the messenger boy go to their funerals to pay respects. Had them all on the same day. At one of them there wasn't anything but Slate Hardware there. Relatives were probably glad we blew him up. I was on the ferry coming back from a selling trip when it happened. A ball of fire come up in the sky and Witty Radder that ran the ferry fell onto his knees-he was some kind of Mennonite, I think-and started mumbling and praying like it was a fast-talking contest. I never heard a word he said, but I reckon God would have taken mercy on him for all the effort he was putting out. The sound didn't come until the fire had grabbed itself together in a ball and turned scarlet. It hit you in the face like a baseball, cracked or blew out most of the windows on the south side of Garrison. That afternoon my father had me carry tape around to all the different places where there was still some window left. Nobody cussed me. They were standing out in the street talking and comparing windows. That was the friendliest I saw this town. My name was Austin Slate and they knew Slate powderhouse had just blew out all their windows, but they didn't cuss me. I guess that was the day this town got civilized."

I asked him what civilized meant.

He took the pipe from his mouth and tapped out the burned load in his palm. "That's when people get along." He handed me the palmful of ash and burned tobacco. "Hold that for me until I find a wastebasket. Can't put ashes on the floor."

He walked over to a shelf and pulled out a brown carton with DAISY RED RYDER printed on the end of it. I knew what that was and my heart started beating fast. "Did you ever shoot a BB gun?" he asked.

"No sir, but I can. I can do it. My brother did it. I can shoot a cannon, too, if I want to."

"We'll see about that." He opened the box and took out the gun. The barrel was black and oily and the stock wooden, engraved with Red Ryder on a horse. $\mathrm{He}$ opened one of the two packages of BBs in the box and carefully poured them click-clicking into the magazine. "All right, what will be our target?"

I put the handful of ashes and burned tobacco into my pocket and looked around. "You mean we'll shoot in here?"

"No, has to be outside; might break something in here. Only place you can shoot inside the store is the basement. Look out there and see if you can see something that won't be broke." He handed me the gun and unlocked the window, cobwebs and dust puffing up as he opened it. We decided to shoot at the metal plaque beside the Yankee cannon. I did not know it then, but the sign explained that the cannon was a remnant of the capture of Fort Smith in 1863 by Brigadier General James C. Blount, who remained until the end of the war, UNDERTAKING PUNITIVE ACTIONS AGAINST THE INDIANS WHO SYMPATHIZED WITH THE CONFEDERACY.

And I did not know that in fourteen years Grandfather would get into his car 
and black out and then smash the wheel off this very cannon, as though to complete our target practice. We took turns. He let me cock the gun for myself and did not tell me how to aim, and so I missed and was jealous of the distant ping that a few of his shots brought. Then he loaded his pipe and sat on the edge of a shelf, allowing me to shoot alone. I kept missing, cocking and shooting, getting more impatient, until he told me to take it easy, I was liable to break a window. I was mad and delighted and voracious to hit the plaque. That ping would have been the highest accomplishment in the world. Higher than being able to roll my stomach like my brother, higher even than having a rubbery neck like an Egyptian dancer, an ability which I had daydreamed about forever and asked for repeatedly, with no luck, in the private prayer that I added onto the Lord's Prayer each night at bedtime. Yes, I would have foolishly traded one ping for that marvelous ability, would have done it in an instant, but I could not at that moment tell God, because praying in the daytime was out of the question. It occurred to me, but I did not actually go through with it. God had a lot to do in the daytime and would not take lightly to being interrupted.

So I just kept peppering the front lawn of the old courthouse, while Grandfather sat there huffing little clouds of Prince Albert, more smell than smoke, staring off into some ancient memory, or perhaps into nothing at all. Once he asked me if there was anybody out there; I told him no, and he said good, he didn't want anybody shooting back. The old courthouse was not yet a national monument then, so there was no reason for people to be wandering around this oldest and deadest part of town. In a few years they would come in droves to see the courthouse where Isaac Parker sentenced more than a hundred-fifty men to be hanged, and to take pictures of the reconstructed gallows, a whitewashed platform built to take sixteen at a time, and to sniff the dank air of the underground jail, which two hundred U.S. marshals at once tried to keep full, from the time Grandfather was born in 1877 through the late nineties, combing seventy-four thousand square miles of Indian Territory for whisky peddlers, burglars, train robbers and murderers-themselves just as crooked as their prey, because six cents a mile and two dollars for an encounter which "endangered life and limb" was not enough to live on. I did not know any of it then, but Grandfather planted a seed of interest in me that day. At some moment in my fever of trying to hit the plaque, perhaps when I was debating whether to ask God for help, he mentioned Belle Starr. He said that he had seen her once at a Fort Smith fair, where they had hired her for local color. He said that she rode sidesaddle and was ugly as a mud fence. And he spoke of Pearl Younger, Belle's bastard daughter by Cole Younger, saying that nobody knew it-again musing to himself between puffs-but Pearl's Hotel was still standing down where First Street used to be. "Nobody knows it," he repeated, "or they've all forgot, but that old hotel is still standing just as high as it was in 1890 when my mother told me that if I got anywhere near First Street at night, I would forfeit my soul to the devil and burn in hell for eternity."

I asked Grandfather what that meant. I had not yet learned that side of theology. Although I knew-or instinctively felt-that God sometimes got angry 
and punished evildoers, I did not yet know that there was a separate and individual power to take care of such matters. I felt that God could take care of it all. Grandfather did not answer, and I asked him again. He still did not answer. His pipe had gone out, and he was sitting very still on the shelf, not looking at me. He was not looking at anything. From the small of my back ice water rose to my brain. I turned away from him and cocked the BB gun.

It was sometime in high school that I first saw Pearl's Hotel. I had not thought of it or even remembered Grandfather's mention of it for many years-but seeing it, I knew without question that it was Pearl Younger's hotel. Standing across the switch tracks against the Arkansas River flood wall, with no other buildings nearby, it was square, two-storied, with a modest Greek cornice above the front door and, strangely, a brand new coat of white paint. I later discovered that the Park Service-or rather one passionately idealistic ranger by the name of Red Puller-was trying to renovate the building and open it as a part of the monument. He was naturally having some trouble convincing the U.S. Government to buy an old whorehouse and display it as a national monument, but he had meanwhile taken it upon himself to finance the painting and was trying to round up a Citizen's Committee to Save Pearl Younger's Hotel, zealous but misguided project for which he earned the title "that idiot Park Ranger" among moderate citizens and the desire, among the more upright ones, to hang him on his own newly reconstructed gallows. He had red hair and buck teeth and worked day and night to reconstruct Fort Smith's history, digging in old records, discovering foundations that had been buried and forgotten for a hundred years, advertising in the newspaper for "elderly Fort Smithians who recall facts about the city from before 1900," begging old law firms for probate records, flying to Washington on his vacation to read Zachary Taylor's memoirs of Fort Smith, even writing letters to a library in France for details on La Salle's journey up the Arkansas River. Red Puller was not a Park Ranger, he was a scholar, and it was from him that I learned what Grandfather did not teach me on the day that we shot the BB gun. I would never have mentioned that incident to Red, as he would doubtless have delivered me a stern and endless lecture on Defiling Public Monuments-even though it had happened many years before-wiping his face with a dark green handkerchief, as he always did, and smiling toothily at odd moments in his monologue. He talked only in monologue, and although I never witnessed one of his interviews with an "elderly citizen who remembers facts," I can safely imagine that he told them more than they told him. He spoke a running barrage of facts, endless details from old plans and records and speeches and newspapers, raw chunks of old Fort Smith gobbled whole, undigested, regurgitated in nineteenth-century phrases, as though he were a living witness to the last century, always just arrived from a journey back in his time-warped mind. He did not seem to enjoy it. There was always heartburn in his faceperhaps not real heartburn, but a kind of psychic heartburn which caused fleeting but regular looks of discomfort-so that his face was always punctuated 
with smiles, heartburn and wipes of the green handkerchief, all at the wrong time and with no sense of climax, as he kept up his endless narrative about the Fort Smith that Grandfather was raised in but did not tell me about, as he sat there, and will always sit in my memory, dead still on a shelf in the musty silent fifth floor of Slate Hardware.

Red loved to talk about the seventy-nine men who actually hanged on the gallows. That one lit him up like a pinball machine. He remembered them in chronological order: Daniel Evans, William Whittington, James Moore, Smoker Mankiller, Sam Fooy and Edmund Campbell, the first six to hang, September 3, 1875; Orpheus McGee, who lured Robert Alexander from his cabin by gobbling like a wild turkey and shot him through the face with a Winchester rifle on April 20, 1874; Dr. Henri Stewart, who had studied medicine at Harvard and become a noted physician, but later ignominiously abandoned his family of five and ran away to Indian Territory to become a train-robber, killing J. B. Jones in an attempted holdup at Caddo, Choctaw Nation, in 1879; Edward Fulsom, a man of such slight build that his pulse beat for one hour and three minutes after the trap had sprung; Jack Woman Killer, who murdered the innocent industrious white farmer Nathaniel Hyatt, mutilating his physiognomy beyond recognition, a deed that surely foreordained his doom in the fiery regions; Tualisto, a Creek Indian who robbed and killed a traveling salesman for money to go to a green-corn dance, suffering his just retribution at the tribal whipping post and at the gallows in Fort Smith, where, just before he left this world, he bragged that each of the four red buttons on his hat represented a man he had killed; a part-Cherokee named Kit Ross, who responded out loud to Judge Parker's fatal sentence, "Well, they done it to me"; Gus Bogles, who in the summer of 1887 killed a man named J. D. Morgan by buckling a strap around his neck and belaboring him with a pistol; a fractious and discourteous prisoner, Bogles tried twice to seize a guard's pistol and once to smuggle himself out of jail in a barrel that had contained sawdust for spittoons, and on his last night he screamed and whooped for no other reason than to annoy his fellow prisoners; Bood Crumpton, who at the youthful age of nineteen shot a friend in the back and dumped his body in a pit near the Pawnee Indian Agency, and whose message from the gallows was doubtless a potent lesson to many a lawless inebriate: To all you who are present, especially the young men-the next time you are about to take a drink of whiskey, look closely into the bottom of the glass and see if you cannot observe in there a hangman's noose. There is where I first saw the one which now breaks my neck; John Thornton, who committed one of the most egregious crimes ever recorded at Judge Parker's court, repeatedly and mercilessly violating his own daughter, a thin and trembling blonde who at a tender age married to escape her father's revolting abuse and was killed by him in the absence of her husband, Thornton emptying a pistol into her body, such a fat and flabby man that when he dropped at the end of a rope blood spurted as the flesh of his neck ripped apart, causing the crowd to shudder with horror and three elderly ladies, who had come together from Towsen 
Street, to faint in unison at the abhorrent sight; Lewis Holder, who robbed and murdered his business associate, dumping his shotgun-riddled body in a gorge in the Choctaw Nation, December 28, 1891, such a cowardly man that upon Judge Parker's pronouncement that he Be hanged by the neck until dead, his face turned an ashen color, a violent tremor shook his body and he let out a scream that was heard in the street outside, and even, one report has it, inside the Slate Hardware Company building some fifty yards away (I interrupted here, asking Red who heard the scream; was it my grandfather? He did not know, as only one of the four newspaper articles on the event carried the scream all the way to Slate Hardware, and they were vague about it.); then he fell to the floor and remained so unresponsive that many thought he had cheated the gallows, but he had not, and awaiting the final day, he begged the guards passing his cell not to hang him, finally threatening that he would return as a spirit and haunt them; even this failed to stay the hand of justice, although later reports had it that indeed some nights unearthly sounds did float from the inky darkness that enveloped the gallows, startling jailers and prisoners alike. And there were the big ones, the gangs-the Starrs, the Daltons, the Rogers, the Cooks, the Bucks. . .

The Bucks were Red's favorites, and I listened closely, again and again, as he spoke of them, for at seventeen I had decided to withdraw from the world and become a historian, a great scholar who would reveal the truth of the old days, calling forth the very shades out of that time and making them dance their dance of death and iniquity. I would capture, tame and wield them like puppets. I listened closely to Red when he spoke of the Bucks, the most depraved outlaws in Indian Territory, a band of five led by Rufus Buck, a full-blooded Euchee Indian, including Sam Sampson and Maoma July, Creek desperados, and Lewis and Lucky Davis, Creek freedmen, a mixture of Negro and Creek-who in thirteen days rampaged across the Creek Nation robbing stores, stealing cattle, shooting a young Negro boy, killing a Negro deputy marshal and committing multiple rapes upon an Indian and a white woman, finally being apprehended after a shootout with a posse of Creek Lighthorsemen and brought to Fort Smith, where the rape of the white woman Rosetta Hassan somehow took precedence over the murder of the Negro deputy and wounding of the Negro boy and rape of the Indian woman, as the indictment that was drawn up stated That Rufus Buck and Lewis Davis and Lucky Davis and Sam Sampson and Maoma July, on the fifth day of August, A. D., 1895, at the Creek Nation, in the Indian country, within the Western District of Arkansas aforesaid, in and upon Rosetta Hassan, a white woman, and not an Indian, feloniously, did ravish and carnally know, contrary to the form of the statute in such case made and provided, and the peace and dignity of the United States of America-the thereby indicted Bucks brought to trial, where the white woman who had been raped-a beautiful and modest woman of thirty years, well proportioned and with a look that betokened a kindly disposition, dressed in nothing that could have been considered gaudy, with skin, it was said, so white that it was almost ghostly-this woman 
forced upon the witness stand to describe the outrage committed upon her by Lucky Davis, the colored brute who had held the muzzle of a Winchester to her forehead and forced her to lie down, testimony which caused the entire courtroom, packed with irate citizens, including representatives from several civic groups, to shed noble and sympathetic tears, of which no one of them was ashamed, not the rough-and-ready deputies, nor even Judge Parker, who, notwithstanding his inurement to savage crimes through long years on the bench, removed his spectacles and was said to have had a suspicious moisture glistening upon his eyelashes. And the attorney appointed for the defense, William M. Cravens, knowing the feeling among the citizenry, stood and said, in what was probably the shortest plea for defense ever recorded, May it please the court and you, gentlemen of the jury, you have heard the evidence. I have nothing to say. And Judge Parker, after the verdict, said to the criminals, The offense of which you have been convicted is one which shocks all men who are not brutal. It is known to the law as a crime offensive to decency, and as a brutal attack upon the honor and chastity of the weaker sex. It is a violation of the quick sense of honor and the pride of virtue which nature, to render the sex amiable, has implanted in the female heart. And on July 1, 1896, the five were led from the underground cell below the courthouse, all perfectly calm, clad in black suits, Maoma July and Lucky Davis wearing large boutonnieres upon the left lapel of their coats, ascending the steps of the gallows and sitting upon the bench while the death warrant was read, after which they stood and Lucky Davis shouted Good-bye, Martha to his sister, who was present, and Rufus Buck's father, a big, heavy old man, got into the jail enclosure and attempted to come up the steps to the platform where his son stood, but, insipidly drunk, he was escorted below, and the condemned stepped forward, none of them showing signs of fear except Lucky Davis, whose face twitched in nervousness as the black cap was placed over his head, and at 1:28 o'clock the trap dropped with its hideous chug and Lewis Davis died in three minutes, his neck broken, as were the necks of Sam Sampson and Maoma July, Rufus Buck and Lucky Davis being strangled to death, Davis' body drawing up several times before it straightened out. And in Rufus Buck's cell, after the execution, was found a photograph of the criminal's mother with a bizarre farewell poem that the condemned had written on the back-a copy of which was the only memento that Red Puller ever gave me, not needing to give me anything else, since he repeated his histories often enough that I could never forget them, not if I tried, for they run in my mind some nights like a muddy river, like the Arkansas River, and there is no stopping them. I happen upon Rufus Buck's poem in the back of a drawer sometimes and re-read it. At the top right-hand corner of the page is the sketch of a robed arm with the forefinger pointing at the title: "MY, dream-1896"; at the bottom of the page is the sketch of a tomb made of natural rock with ivy growing around the base of the cross; above the ivy, across the page, is written "virtue and resurrection"; and on the cross: 


$\begin{array}{cl} & \text { H } \\ & \text { O } \\ & \text { L } \\ \text { FATHER } & \\ & \text { SON } \\ \text { G } & \\ \text { H } \\ \text { O } \\ \text { S } \\ \text { T }\end{array}$

The poem, above the tomb, reads:

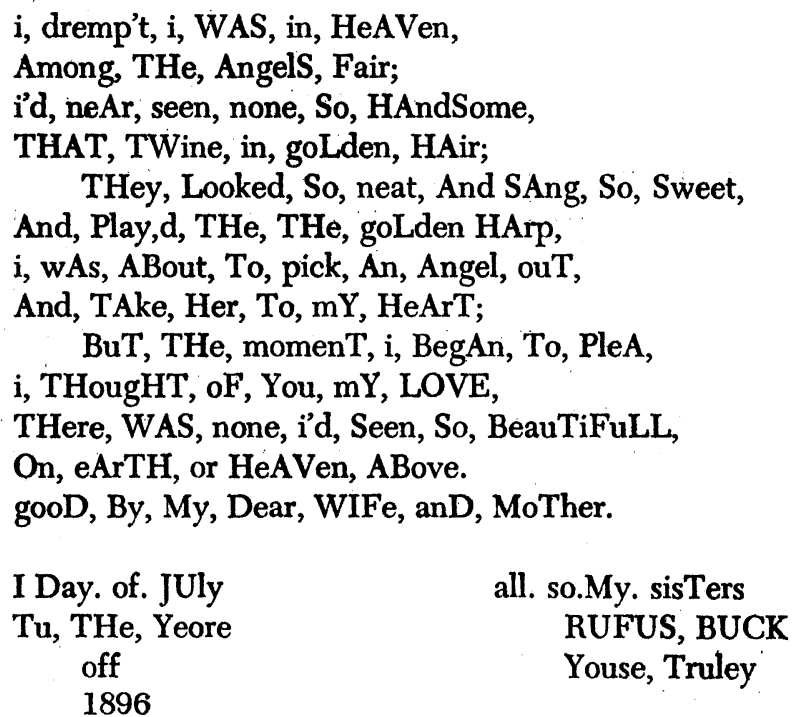

There was another souvenir-given to me by Grandfather that Saturday afternoon at Slate Hardware. It was a .44 caliber bullet taken from the bandolier Belle Starr was wearing the day she was killed. Apparently it had been given to Grandfather by his father, who had received it from George Maledon, Judge Parker's hangman. Maledon probably got it from one of the deputies investigating Belle Starr's murder. I heard much later, from a second cousin, that Grandfather's father and Maledon were buddies. The immediate family was ashamed that Great-Grandfather was the friend of a hangman, and it was seldom mentioned. When I later showed the bullet to Red Puller, he denied that it could have been Belle Starr's. He said that she did not have a .44 caliber gun-that she had never had one as far as he knew. But Red could not end with this simple statement; he had to tell me Belle Starr's entire history for the umpteenth time; in his forever serpentine and inexhaustible sentences to spin out the tale of how, born Myra 
B. Shirley, she turned bad while still a teenager in Missouri, becoming a Confederate spy and assassin after her brother was killed by Yankees, and her family had to move, due to her reputation, to Texas, where in 1867 she fell into an illicit relationship with Cole Younger and gave birth to Pearl Younger, who-despite her later reputation as the Queen of the Madams in a town known for six hundred miles for its houses of ill fame-never succeeded in matching her mother's infamy, as Belle Starr rode across Texas, Missouri and Arkansas, leader of the Reed Gang of horse thieves, burglars and whiskey-runners, flouting the canons of respectability by her open and lascivious relationship with Jim Reed and later with Tom Starr, a Cherokee rebel so widely known for his power and ruthlessness that the tribal council issued a separate treaty for him after the Civil War, and later with Sam Starr, together with these ruffianly lovers sweeping across Indian Territory in general fornication and merriment, from bad towns like Vinita, Claremore and Tulsey Town to hell-holes like Catoosa, where inebriated riders raced their ponies up and down Main Street, whooping mightily and emptying their revolvers in the sky, and not infrequently in dark, smoke-filled pool-halls loud arguments and smouldering grudges flared up, but where the name Belle Starr was feared by even the most heedless and depraved-as she brazenly abandoned Tom Starr and married young Sam Starr, living with him at the end of a canyon on the Canadian River under Hi-Early Mountain, Indian Territory, named by her "Younger's Bend" after her first lover, until together she and Sam Starr were sentenced by Judge Parker to nine months at the House of Correction in Detroit for stealing horses from a neighbor's corral, a just but moderate sentence which in no way reformed them, as together on Friday night, a week before Christmas, 1886, they attended a dance at the home of Mrs. Lucy Suratt on the Canadian River near Whitefield, where Sam Starr drank to excess, his ill-tempered glare falling upon Frank West, a deputy who was attending the dance, and he said You are the son of a bitch who shot me and killed my horse that day in the cornfield, and he drew his gun and shot West through the neck, and West drew his gun and shot Starr through the heart, and both men were dead within two minutes. And in 1888 Belle Starr, now forty years old, married a tall young Creek named Jim July, sixteen years her junior, an intelligent but vicious man, continuing to live at Younger's Bend together with him and Pearl (who, now grown, had come the year before and readily taken up the free and easy life at Younger's Bend), until on February 2, 1889, Belle accompanied Jim July fifteen miles toward Fort Smith, where he was to be tried for larceny, and on her way home visited and had some argument with a neighboring farmer over a proposed land lease. That was the last time she was seen alive. A few hours later a man named Milo Hoyt, who ran a ferry on the Canadian River, heard shots and found Belle Starr lying face down in the mud, a charge of buckshot through her back and birdshot in her face. Jim July tried to get the farmer indicted for her murder, but there was no evidence, and a few months later July jumped bond on a horse-theft charge and was brought into Fort Smith mortally wounded by a U.S. marshal outside Ardmore in the Chickasaw Nation, and when Jim July knew he was dying, he called the marshal, stating that he 
had a confession to make and would tell it to no man but the one who had killed him. But the marshal arrived too late. Only then did the boatman Milo Hoyt reveal that July had offered him two hundred dollars to kill Belle Starr, apparently because she had caught him in an adulterous relationship with a Cherokee woman at Briartown and was harassing him, Hoyt refusing the invidious bribe, July having ridden away, shouting, Hell, I'll kill the old hag myself and spend the money for whisky.

And so I got a bullet commemorating that event, but was too young when I got it to care-perhaps also a little scared of it. Because Grandfather was bribing me when he gave me Belle Starr's bullet. We had to go back downstairs, but first Grandfather had to wake up. He had spells; that's what they called them later. At first, he seemed to be asleep with his eyes open. I still had not hit the sign, but I figured we should be going back down the elevator-if it went down. I only knew for sure that it went up. I knew a real elevator went down, too, but this was not a real one. It was too wide and had no walls, and you could almost feel a wind blowing when it rode you through the darkness. Grandfather had a spell before we went down. He sat there without moving, and I did not know what to say because it was impolite to tell grownups when to leave. There was a drip of saliva under the bowl of his pipe, and he was staring into space without expression. The sun was going down. It occurred to me that he might be deciding whether to give me the $\mathrm{BB}$ gun, so I put it back into the box and stared at it lovingly. Grandfather stood up and my heart jumped. I figured he was going to give it to me. But he walked past me down the aisle without saying anything, and I followed, disappointed to have left the BB gun. He stopped near a wall where there were garden plows hanging on nails. Then he took off his coat and hung it on a plow. That seemed strange. Then he took off his shirt. His back was to me, and I could not tell what he was doing until he had taken it off. In the gloom his back was stark white. He turned around and walked toward me, and I did not move. He sat on a shelf and began taking his shoes off. There was something funny about the way he was moving. He moved like there was nothing holding him back, as if he were suddenly not an old man. Or maybe not any man, maybe something more like the dream men who wandered in the different air of my sleep. His socks were thin bands of faded scarlet which he took off and stuffed carefully into his shoes. His splayed skinny toes seemed to work and spread at odd angles when he stood up. Then he took off his pants, folding and carefully placing them on a box of ax handles. He stood in orange dust-light in underwear with faded candy canes running at angles on them. His lizard eyes were floating in another world. I tried to move behind the large spindle of rope, but I feared that he would awaken and be ashamed and I would be ashamed. I knew he was asleep, or gone somewhere, and I should not disturb him. I did not want him to take off his shorts, but he did. His little fluff of hair was red, and the idea came to me that they must be red when people were old.

He looked through me and said, "Nora, put on the comfort. It's cold tonight." 


\section{I did not move.}

Then he went to the plows and unhooked something and put it on his legsonly there was nothing there-and he unhooked another nothing and put it on his top, rapidly buttoning imaginary buttons. And he lay down on the splintery pitted planks of the floor and said "Good night, Nora." Nora was Grandmother, but she was dead and not there. She slept under the green lawn by the Arkansas River; that was where dead people went, and they stayed there-I was pretty sure of that. Maybe Grandfather was pretending that he was at the green lawn. But he did not pretend; no big people pretended. When his eyes shut and his face went to sleep, I could move. I went behind the spindle and hid, but the room was getting darker, and when I looked out at Grandfather, he seemed to be settling into the dust of the floor. I did not want him to disappear, because then he would be everywhere in the spreading darkness of the room. If he disappeared, I could not tell where he was. If he put his clothes back on he would not disappear, and so I wished them back on him, but they did not go. Then I prayed, saying the Lord's Prayer very fast so I could get to the personal one at the end and ask God to put Grandfather's clothes back on. It was dark enough to pray now.

God did not put Grandfather's clothes back on.

The smell of rope and of the dust of a hundred years and the darkness that was spreading from corners and shelves all seemed to diminish at once, as my nose was filled with the charred wet briar-wood redolence of Grandfather's pipe. It swarmed in my nose like something alive and diffused into my cheeks, and for a moment I was dizzy. I could not see the pipe. I wanted to see it and take it and put it under my nose and smell it again. I would give it to Grandfather and he would awaken. He always put his pipe in his mouth when he awakened. When he lit it, he came to life. I would help him. I went to his coat and found the pipe in a side pocket, then knelt beside him. I stuck my nose in the bowl of the pipe and smelled as hard as I could. His face was so asleep that it would be wrong to awaken him. I would get into trouble. But soon the room would be all dark and the man who rolled the elevator up and down would go home for the night, and we would be stuck here. Grandfather's face was purple with sleep.

I said, "Grandfather, will you smoke your pipe?"

He did not move. So I put the pipe in his mouth, not touching his lips, but prying them apart with the stem and pushing it in. When it was upright in his mouth, I let go. It fell to the floor and lay in a crack between planks. I grabbed it and stuck it into his mouth again, wincing as it clicked against a tooth. I held it upright and said, "Grandfather, will you wake up and smoke your pipe?"

He did not do it.

I said, "God, will you wake Grandfather up and make him smoke his pipe?" God waited a few moments, as I continued to hold the pipe, then woke Grandfather up. His eyes switched open, and I could feel the grip of his mouth harden around the pipe. He propped himself up and took something out of the air and examined it. "Six-thirty," he said, and stood up, the pipe still in his mouth, and 
put his clothes back on. When his coat was on, he stared at the wall of garden plows. His hand reached up as if to touch one of them, but it did not. He turned, his hand still held out. "What are you doing here . . . boy?"

I could not answer that.

His arm came slowly to his side, and he seemed in the shadows to become smaller, his thin-boned shoulders curling forward around his lizard years. He stared at me out of the shadows of his eye sockets, but he was Grandfather now, standing in his clothes with his pipe in his mouth. He shuffled forward and his hand touched the open box of ax handles. He pulled one half-way out and looked at it as if he did not know what it was. Then he let it drop, turned and shuffled down the aisle toward the elevator. I followed at a distance.

I stepped gingerly onto the elevator platform, afraid that the black man who controlled it would be caught off guard and we would fall to the basement. Grandfather pulled the swaying rope that was tied to the black man and greasy cables began to feed us downward, past shadowy floors, toward my father and the front door of Slate Hardware. I desired the front door of Slate Hardware. When I walked through it, I would not stop at the cannon plaque to count dents or search for copper BBs in the yard of the courthouse; I would just get into the Studebaker and leave with Father and go home to Mother. Grandfather stooped in the corner of the elevator, the signal rope playing through his circled hand. I looked up through the dim mauve void of the shaft and saw that what had happened would have to remain secret. I had few secrets, but I would not even be able to tell Mother about this.

The wind played across my neck as the platform descended toward her. I would crawl into bed with her and sleep in the crack between her and Father. I had done that once before when a bear lumbered up the steps in my dream, stood on his hind legs and switched on a light bulb, which danced and jiggled across his huge brown head, as he smiled and said softly, Come out Austin, we know you are there, and I hid behind hollow cardboard boxes and fainted awake. There were bears in this store, but they were all above and below the ground floor, except the one on the bullet display. The ground floor was just a normal place. Up here the bears awakened at nightfall. Maybe the elevator man fed them before he went home from work-or they fed themselves in the forest of hardware, padding quietly past thick timbers, breathing on the metal of stoves and engines. I stood in the center of the platform so they could not reach me as we passed downward, silently daring them to try when we neared the first floor. But I looked at Grandfather and saw that he had let go of the signal rope, turned toward me and was shuffling across the moving platform, as the first floor came into view and then disappeared above, and we were swallowed in dark, my stomach tugging gently downward as he brushed by me-a shadow of burned tobacco. At his touch I half turned, losing my balance and grabbing the air to not fall. Grandfather had left the controls, and I must not move my feet from the center of the platform. He was absorbed in the cold that breathed across me. He had gone off to finish what he was doing. He would call for me, and I would have to take off my clothes and walk through the basement to him. 
Bears would stop and wait. If I looked up into the gloom of the shaft, the elevator man would take me to him. I lost my balance again, and my arms jerked to keep my feet exactly where they stood. Balance regained, I hunched my head between my shoulders and methodically felt the blackness around me with fingers stiffened into nails. I protected a circle around me.

A match flared not far away, illuminating Grandfather's face and pipe. $\mathrm{He}$ lit the pipe, then switched on a light bulb that hung in front of his head, and his forehead was like white paper that you could see through. He stood in the pool of light, shuffling through a metal box on a long table. Then the light was switched out, and the glowing pipe was above me, speaking, "I got a present for you boy. Hold out your hand."

Something small and cold was put in my palm.

"That's a bullet," he said. "Belle Starr was carrying it when they shot her."

"Yessir."

"Do you like that present, Austin?" There was a tone in his voice that I had never heard before. "Do you, boy?"

"Yessir."

"They took it off her dead body."

I did not know what he was talking about.

"It's worth money . . . I hope that little present, I hope it will occupy your mind." His voice seemed to be asking me for something.

I squeezed the bullet in my wet hand. "Yessir."

"My father gave it to me." For a second his hand touched my shoulder. And then the question was out of his voice. "Anyway, that's the best I can do. Don't lose it." 